\title{
PENGARUH PEMBERIAN EKSTRAK ETANOL DAUN KEMANGI (Ocimum basilicum L.) TERHADAP JUMLAH SEL SPERMATOGENIK TIKUS PUTIH (Rattus norvegicus) GALUR WISTAR JANTAN YANG DIINDUKSI MONOSODIUM GLUTAMAT
}

\author{
Mahidin $^{1}$, Andi Muh. Maulana ${ }^{1}$, Susiyadi $^{1}$ \\ ${ }^{I}$ Fakultas Kedokteran, Universitas Muhammadiyah Purwokerto
}

\begin{abstract}
ABSTRAK
Latar Belakang : Penggunaan Monosodium Glutamat (MSG) secara berlebihan dan atau penggunaan dalam jangka waktu yang cukup lama akan berbahaya bagi tubuh karena dapat menyebabkan terbentuknya radikal bebas dan menimbulkan stres oksidatif. Radikal bebas dan stres oksidatif dapat terjadi pada testis dan sistem hipotalamus-hipofisis-gonad yang dapat menyebabkan terganggunya proses spermatogenesis sehingga terjadi penurunan jumlah sel spermatogenik. Kerusakan sel dan jaringan yang diakibatkan oleh radikal bebas dapat dicegah dan diperbaiki oleh senyawa flavonoid sebagai antioksidan alami terkandung dalam daun kemangi (Ocimum basilicum L.).

Tujuan : Mengetahui pengaruh pemberian ekstrak etanol daun kemangi (Ocimum basilicum L.) terhadap jumlah sel spermatogenik tikus putih (Rattus norvegicus) galur wistar jantan yang diinduksi MSG.

Metode : Tikus putih (Rattus norvegicus) galur wistar jantan sebanyak 30 ekor dibagi menjadi 5 kelompok, yang terdiri dari kelompok kontrol negatif (K-), kelompok kontrol positif (K+), kelompok perlakuan 1 (P1), kelompok perlakuan 2 (P2), dan kelompok perlakuan 3 (P3). Hewan coba akan diterminasi, dibedah, diambil organ testisnya, dan selanjutnya dilakukan pembuatan preparat histolgi dengan pewarnaam HE. Preparat tersebut diamati menggunakan mikroskop cahaya dengan pembesaran 400X dan dihitung menggunakan aplikasi image-J.

Hasil : Kelompok P1, P2, dan P3 memiliki jumlah sel spermatogenik yang lebih banyak dibandingkan dengan kelompok kontrol positif $(\mathrm{K}+)$ yang menunjukan bahwa ekstrak etanol daun kemangi (Ocimum basilicum L.) dapat memperbaiki jumlah sel spermatogenik yang rusak akibat pemberian MSG.

Kesimpulan : Pemberian ekstrak etanol daun kemangi (Ocimum basilicum L.) dapat mempengaruhi jumlah sel spermatogenik tikus putih (Rattus norvegicus) galur wistar jantan yang diinduksi MSG.
\end{abstract}

Kata Kunci: ekstrak etanol daun kemangi (Ocimum basilicum L.), sel spermatogenik, Monosodium Glutamat(MSG) 


\title{
THE EFFECT OF EXTRACT ETANOL OF BASIL LEAF (Ocimum Basilicum L) TO THE NUMBER OF WHITE GALUR WISTAR MALE RAT CELLS SPERMATOGENIC (Rattus Norvegicius) INDUCED WITH MONOSODIUM GLUTAMATE
}

\author{
Mahidin $^{1}$, Andi Muh. Maulana ${ }^{1}$, Susiyadi $^{1}$ \\ ${ }^{1}$ Faculty of Medicine, Universitas Muhammadiyah Purwokerto
}

\begin{abstract}
ABSTRACK
Background : The excessive use of Monosodium Glutamate (MSG) and or a long-term use of MSG will be harmful to its body as it may affect free radicals to form and cause oxidative stress. Free radicals and oxidative stress is able to occur in the testis and hipotalamus-hipofisis -gonad system carrying a cause of disruption spermatogenesis process which by then resulted in a decrease number of spermatogenic cells. The damage of cells and system caused by free radicals can be prevented and improved by flavonoid compounds function as natural antioxidants contained in basil leaves (Ocimum Bacilimum)

Purpose: To find out the effect of basil leaf ethanol extract (Ocilum Basilimum L.) to the number of spermatogenic cells of white male rat (Rattus norvegicus) in induction line.

Method : As many as 30 white males wistar rat divided into 5 groups, consisting of negative control group (K-), positive control group $(\mathrm{K}+)$, treatment group $1(\mathrm{P} 1)$, treatment group 2 (P2), and treatment group 3 (P3). The rat is then laid in surgery and was taken its testicular organs which by then made into histology preparat with HE staining. The final preparation was observed by using a Microsoft light with 400X enlargement and calculated by using the application image-J.

Result : The groups of P1, P2, and P3 had more spermatogenic cells number compare to that of positive control group $(\mathrm{K}+)$ which then showed that basil leaf ethanol extract (Ocimum Basilicum L.) could likely to improve the number of spermatogenic cells damaged by MSG.

Conclusion : The administration of basil leaf extract of ethanol (Ocimum basilicum L.) can affect the number of spermatogenic cells of galur wistar white male rat (Rattus norvegicus) induced by MSG.
\end{abstract}

Keywords : basil leaf extract of ethanol (Ocimum Basilcum L) spermatogeni cells, Monosodium Glutamate (MSG) 


\section{PENDAHULUAN}

Monosodium Glutamat (MSG) merupakan bubuk kristal berwarna putih yang sudah lama digunakan sebagai bahan tambahan pada berbagai jenis makanan. MSG digunakan di berbagai negara sebagai penguat dan penyedap rasa ${ }^{1}$. Penggunaan MSG yang diperbolehkan atau Acceptable Daily Intake (ADI) ditetapkan oleh World Health Organization (WHO) yaitu sebesar $120 \mathrm{mg} / \mathrm{kgBB} / \mathrm{hari}^{2}$. Penggunaan MSG di dunia semakin meningkat dengan rata-rata konsumsi 3$4 \mathrm{~g} /$ hari dari tahun 1995 sampai tahun $2007^{3}$.

Penggunaan MSG secara berlebihan dan atau penggunaan dalam jangka waktu yang cukup lama akan berbahaya bagi tubuh ${ }^{4}$. Penggunaan MSG yang berlebihan dapat menyebabkan terbentuknya radikal bebas dan menimbulkan stres oksidatif ${ }^{5}$. Radikal bebas dan stres oksidatif pada testis akan mengakibatkan kerusakan dan penurunan jumlah sel spermatogenik yang dapat menggangu proses spermatogenesis sehingga menyebabkan produksi spermatozoa di dalam testis berkurang 6 .

Radikal bebas dan stres oksidatif yang diakibatkan MSG juga akan menimbulkan adanya efek neurotoksin pada sistem hipotalamus-hipofisis-gonad. Radikal bebas dan stres oksidatif tersebut menimbulkan kerusakan pada nukleus arkuata di hipotalamus yang menyebabkan terjadinya penurunan hormon reproduksi, sehingga dapat mengganggu proses spermatogenesis dan mengakibatkan diameter tubulus semineferus mengecil, jumlah lapisan sel-sel spermatogenik berkurang dan kepadatan sel interstisial menurun ${ }^{7}$. Peningkatan radikal bebas dan stress oksidatif pada sistem reproduksi dapat menyebabkan infertilitas, dan sekitar 36 persen kasus infertilitas terjadi pada lakilaki ${ }^{8,9}$.

Kerusakan sel dan jaringan yang diakibatkan oleh radikal bebas dapat dicegah dan diperbaiki oleh senyawa flavonoid ${ }^{10}$. Flavonoid sebagai antioksidan alami terkandung dalam daun kemangi (Ocimum basilicum L.) ${ }^{11}$. Kemangi (Ocimum basilicum L.) juga mengandung $\operatorname{arginin}^{12}$. Arginin merupakan asam amino non-esensial yang berperan dalam sistem pertahanan tubuh sebagai imunitas seluler dan juga berperan aktif dalam proses spermatogenesis (pembentukan spermatozoa) $)^{13}$.

Oleh karena itu, peneliti tertarik untuk melakukan penelitian tentang pengaruh pemberian ekstrak etanol daun kemangi (Ocimum basilicum L.) terhadap jumlah sel spermatogenik tikus putih (Rattus norvegicus) galur wistar jantan yang diinduksi MSG

\section{BAHAN DAN METODE}

Penelitian ini menggunakan jenis penelitian eksperimental laboratorium dengan rancangan penelitian post test only controlled group design. Subyek penelitian yang digunakan pada penelitian ini yaitu 30 tikus (Rattus norvegicus) galur wistar jenis kelamin jantan yang berusia 8-12 minggu dengan berat badan 200-300 gram yang didapatkan dari MS. BRAM MOUSE FARM. Hewan coba Hewan coba diberi pakan standar AD-2 dan air minum berupa akuades selama proses penelitian.

Hewan coba kemudian diaklimatisasi selama 5 hari, kemudian dibagi menjadi 5 kelompok, yang terdiri dari kelompok kontrol negatif (K-) yang tidak diberikan 
MSG ataupun ekstrak etanol daun kemangi (Ocimum basilicum L.), kelompok kontrol positif $(\mathrm{K}+)$ yang hanya diberikan MSG dengan dosis $7 \mathrm{~g} / \mathrm{kgBB} / \mathrm{hari}$, kelompok perlakuan 1 (P1) sebagai kelompok perlakuan 1 yang diberikan MSG dengan dosis $7 \mathrm{~g} / \mathrm{kgBB} / \mathrm{hari}$ kemudian diberikan ekstrak etanol daun kemangi (Ocimum basilicum L.) dengan dosis 87,5 $\mathrm{mg} / \mathrm{kgBB} /$ hari, kelompok perlakuan 2 (P2) yang diberikan MSG dengan dosis $7 \mathrm{~g} / \mathrm{kgBB} /$ hari kemudian diberikan ekstrak etanol daun kemangi (Ocimum basilicum L.) dengan dosis $175 \mathrm{mg} / \mathrm{kgBB} / \mathrm{hari}$, dan kelompok perlakuan 3 (P3) yang diberikan MSG dengan dosis $7 \mathrm{~g} / \mathrm{kgBB} /$ hari kemudian diberikan ekstrak etanol daun kemangi (Ocimum basilicum L.) dengan dosis 350 $\mathrm{mg} / \mathrm{kgBB} / \mathrm{hari}$

Monosodium Glutamat (MSG) yang digunakan berupa MSG food yang didapatkan dari PT. Global Chemindo Megatrading Semarang. MSG tersebut dilarutkan dengan akuades sebanyak 2 cc. MSG diberikan secara oral menggunakan sonde lambung diberikan selama empat belas hari. Ekstrak etanol daun kemangi (Ocimum basilium L.) yang akan digunakan didapatkan dari PT. LANSIDA Yogyakarta. Ekstrak etanol daun kemangi (Ocimum basilium L.) dilarutkan dengan Na-CMC $1 \%$ sebanyak 2 cc. Dosis ini diberikandiberikan secara oral menggunakan sonde lambung selama sepuluh hari.

Setelah proses perlakuan selesai, kemudian hewan coba akan diterminasi dengan metode cervical dislocation, dibedah, dan diambil organ testisnya. Organ testis yang sudah diambil kemudian akan dibersihkan, difiksasi dan dibuat preparat histologi menggunakan metode pewarnaan HE (Hematoxylin-Eosin). Setiap ekor tikus putih (Rattus norvegicus) galur wistar jantan akan dibuat tiga buah preparat. Preparat histologi yang sudah jadi kemudian diamati menggunakan mikroskop cahaya Olimpus CX-21 dengan pembesaran 400X dan dihitung menggunakan aplikasi image-J.

Jumlah sel spermatogenik yang akan diamati dan dihitung meliputi jumlah spermatogonia, spermatosit, spermatid, serta jumlah total sel spermatogenik. Pengamatan akan dilakukan pada 5 tubulus seminiferous yang memiliki bentuk hampir sama pada masing-masing preparat. Jumlah sel spermatogenik akan dihitung kemudian dirata-rata hasilnya.

Hasil yang sudah didapatkan kemudian dilakuakan analisis data dengan uji normalitas menggunakan Saphiro-Wilk, kemudian dilanjutkan dengan uji homogenitas menggunakan Levene's test. Data yang sudah dinyatakan normal dan homogen akan dilanjutkan dengan uji hipotesis menggunakan One-way Anova dengan tujuan untuk mengetahui apakah terdapat pengaruh pemberian ekstrak etanol daun kemangi (Ocimum basilicum L.) terhadap jumlah sel spermatogenik tikus putih (Rattus norvegicus) galur wistar jantan yang diinduksi MSG atau tidak, kemudian untuk mengetahui perbedaan antar kelompok dilakukan uji post hoc dengan LSD

HASIL

Hasil pengamatan dan perhitungan jumlah sel spermatogenik menunjukan rata-rata jumlah sel 
spermatogenik pada masing masing kelompok sebagai berikut: Kelompok kontrol negatif (K-) menunjukan hasil rata-rata sel spermatogonia sebanyak 142,48 , sel spermatosit sebanyak 235,788 , sel spermatid sebanyak 182,294 dan jumlah total sel spermatogenik sebesar 560,562. Kelompok kontrol positif $(\mathrm{K}+)$ didapatkan rata-rata sel spermatogonia sebanyak 78,186, sel spermatosit sebanyak 121,812 , sel spermatid sebanyak 98,184 dan jumlah total sel spermatogenik sebesar 298,182. Kelompok perlakuan 1 (P1) didapatkan ratarata sel spermatogonia sebanyak 93,014, sel spermatosit sebanyak 151,574, sel spermatid sebanyak 120,214 dan jumlah total sel spermatogenik sebesar 364,802. Kelompok perlakuan $2(\mathrm{P} 2)$ didapatkan rata-rata sel spermatogonia sebanyak 114,6, sel spermatosit sebanyak 185,786, sel spermatid sebanyak 130,134 dan jumlah total sel spermatogenik sebesar 430,52. Kelompok perlakuan 3 (P3) didapatkan didapatkan ratarata sel spermatogonia sebanyak 126,332, sel spermatosit sebanyak 203, 374, sel spermatid sebanyak 146,652 dan jumlah total sel spermatogenik sebesar 476,358 (Gambar 1 dan gambar 2).

Data yang diperoleh kemudian dilakukan analisis data. Uji normalitas menggunakan ShapiroWilk menunjukkan bahwa data terdistribusi normal dengan p>0,05 (Tabel I). Uji homogenitas dengan menggunakan Levene's test menunjukkan bahwa varian data homogen sengan $\mathrm{p}>0,05$ (Tabel II). Uji hipotesisnya menggunakan One-way Anova memiliki hasil $\mathrm{p}<0,05$ yang menunjukan bahwa terdapat pengaruh
Mengetahui pengaruh pemberian ekstrak etanol daun kemangi (Ocimum basilicum L.) terhadap jumlah sel spermatogenik tikus putih (Rattus norvegicus) galur wistar jantan yang diinduksi MSG. Hasil uji LSD menunjukan terdapat perbedaan antar kelompok keculai antara kelompok dengan $\mathrm{p}<0,05$.

\section{DISKUSI}

Hasil penelitian ini menunjukkan kelompok kontrol positif $(\mathrm{K}+)$ yang hanya diberikan MSG 7 $\mathrm{g} / \mathrm{kgBB} / \mathrm{hari}$ menunjukan hasil lebih rendah yaitu dengan rata-rata sel spermatogonia sebanyak 78,186 , sel spermatosit sebanyak 121,812 , sel spermatid sebanyak 98,184 dan jumlah total sel spermatogenik sebesar 298,182 dibandingkan dengan kelompok kontrol negatif (K-) yang memiliki hasil rata-rata sel spermatogonia sebanyak 142,48 , sel spermatosit sebanyak 235,788 , sel spermatid sebanyak 182,294, dan jumlah total sel spermatogenik sebesar 560,562.

Hasil penelitian ini sesuai dengan penelitian sebelumnya yang menunjukan bahwa bahwa dengan pemberian MSG sebanyak $500 \mathrm{mg} / \mathrm{mL}$ selama 14 hari menunjukkan distorsi pada jaringan testis, disorganisasi sel tubulus seminiferus, penurunan jumlah spermatogonia, dan penurunan sel sperma matang di dalam tubulus seminiferus, serta sel leydig lebih jarang. Pemberian MSG $1 \mathrm{~g} / \mathrm{mL}$ selama 14 hari menunjukkan bentuk tubulus seminiferus tidak beraturan dan ukurannya yang berkurang, peningkatan ruang pada jaringan ikat interstisial, dan terjadi penurunan jumlah sel sperma di lumen tubulus, serta penurunan populasi sel leydig ${ }^{14}$. 
Kelompok P1, P2, dan P3 merupakan kelompok perlakuan yang diberikan ekstrak etanol daun kemangi (Ocimum basilicum L.) dengan dosis 87,5 $\mathrm{mg} / \mathrm{kgBB} / \mathrm{hari}, \quad 175 \mathrm{mg} / \mathrm{kgBB} / \mathrm{hari}, \quad$ dan 350 $\mathrm{mg} / \mathrm{kgBB} /$ hari. Ekstrak etanol daun kemangi (Ocimum basilicum L.) ini diberikan selama 10 hari setelah pemberian MSG. Hasilnya kelompok P1, P2, dan P3 ini memiliki jumlah sel spermatogenik yang lebih banyak dibandingkan dengan kelompok $\mathrm{K}+$ sebagai kelompok kontrol positif, yang menunjukan bahwa ekstrak etanol daun kemangi (Ocimum basilicum L.) dapat memperbaiki jumlah sel spermatogenik yang rusak akibat pemberian MSG.

Flavonoid merupakan salah satu senyawa metabolit sekunder yang paling banyak ditemukan di dalam tumbuhan. Flavonoid termasuk dalam golongan senyawa phenolik dengan struktur kimia C6-C3-C6 ${ }^{15}$. Kandungan flavonoid dalam daun kemangi memiliki subgrup seperti flavone, flavonol, falvonone ${ }^{16}$.

Flavonoid merupakan senyawa yang berperan sebagai antioksidan. Mekanisme antioksidan dari flavonoid adalah pertama sebagai senyawa yang paling efektif sebagai scavanger spesies reaktif bekerja dengan cara mentransfer atom $\mathrm{H}^{+}$. Kedua pencegahan terbentuknya ROS (Reactive Oxygen Species) oleh flavonoid dilakukan dengan cara mencegah reaksi redoks yang dapat menghasilkan radikal bebas yang baru. Ketiga flavonoid merupakan antioksidan yang berperan dalam melindungi antioksidan lipofilik sehingga dapat menguatkan antioksidan seluler didalam $\operatorname{tubuh}^{17}$.
Pengaruh flavonoid yang lain adalah dapat meningkatkan proses regenerasi dari sel. Flavonoid meningkatkan proses regenerasi dengan cara mendestruksi radikal bebas, menyediakan substrat kompetitif untuk lipid tak jenuh dalam membran dan atau mempercepat mekanisme perbaikan membran sel yang rusak ${ }^{18}$.

Senyawa kimia lain yang terdapat dalam daun kemangi adalah asam amino arginin ${ }^{19}$. Asam amino arginin dapat meningkatkan hormon testosteron dan berperan dalam proses spermatogenesis ${ }^{20}$. Testosteron mengontrol perkembangan organ reproduksi seperti pada proses spermatogenesis yaitu diperlukan pada saat pembelahan sel-sel germinal untuk spermatogenesis (pembentukan spermatozoa) dan mengontrol perkembangan tanda seks sekunder pada pria berupa pembesaran laring, perubahan suara, pertumbuhan rambut ketiak, pubis, dada, kumis dan jenggot serta untuk pertumbuhan otot dan tulang ${ }^{21}$.

Asam amino arginin juga berfungsi sebagai pembentuk $\mathrm{GnRH}^{22}$. GnRH yang dihasilkan oleh hipotalamus akan menimbulkan pelepasan FSH dan LH. FSH berfungsi untuk pematangan sperma oleh sel sertoli didalam testis dan mengatur spermatogenesis didalam testis. FSH berikatan dengan reseptor spesifik FSH yang berada melekat didekat sel sertoli didalam tubulus seminiferus. FSH ini akan mengakibatkan sel sertoli untuk tumbuh dan menghasilkan unsur-unsur yang dibutukan dalam proses spermatogenik. LH berfungsi untuk merangsang sel leydig untuk sintesis hormon testosteron. Secara bersamaan hormon testosteron yang 
yang dihasilkan berdifusi ke dalam tubulus seminiferus juga memiliki efek trofis yang kuat terhadap spermatogenesis, oleh karena itu dibutuhkan peran FSH dan testosteron dalam proses spermatogenesis ${ }^{23}$.

\section{KESIMPULAN}

Pemberian ekstrak etanol daun kemangi

(Ocimum basilicum L.) dengan dosis 87,5 $\mathrm{mg} / \mathrm{kgBB} / \mathrm{hari}, \quad 175 \mathrm{mg} / \mathrm{kgBB} / \mathrm{hari}, \quad$ dan 350 $\mathrm{mg} / \mathrm{kgBB} / \mathrm{hari}$ dapat mempengaruhi jumlah sel spermatogenik tikus putih (Rattus norvegicus) galur wistar jantan yang diinduksi MSG

\section{UCAPAN TERIMAKASIH}

Kami ucapkan terimakasih kepada Fakultas

Kedokteran Universitass Muhammadiyah Purwokerto,

Laboratorium Farmakologi Fakultas Kedokteran

Universitas Jendral Soedirman, Laboratorium Riset

Fakultas Kedokteran Universitas Jendral Soedirman,

serta semua pihak yang telah mendukung dan membantu penelitian ini.

\section{REFERENSI}

1. Sukmaningsih. A. A. SG. A, Ermayanti. I. G. A. M., Wiratmini. N. I., \& Sudatri. N. W.. (2011). Gangguan spermatogenesis setelah pemberia.n monosodium glutamat pada mencit (Mus musculus L.). Jurnal biologi. 15(2): 49-52.

2. Yonata. A. \& Iswara. I.. (2016). Efek toksik konsumsi monosodium. Majority. 5(3): 100-104.

3. Contini, M. del C., Fabro, A., Millen, N., Benmelej, A., Mahieu, S., 2017. Adverse effects in kidney function, antioxidant systems and histopathology in rats receiving monosodium glutamate diet. Experimental and Toxicologic Pathology. doi:10.1016/j.etp.2017.03.003

4. Jinap. S \& Hajeb. P.. (2010). Glutamate, its applications in food and contribution to health. Elsevier. 55(1): 1-10.

5. Sukmaningsih. A. A. SG. A, Ermayanti. I. G. A. M., Wiratmini. N. I., \& Sudatri. N. W.. (2011). Gangguan spermatogenesis setelah pemberia.n monosodium glutamat pada mencit (Mus musculus
L.). Jurnal biologi. 15(2): 49-52.

6. Hadi. R. S.. (2011). Apoptosis pada sperma sebagai pertanda adanya gangguan kesuburan pria. Majalah kesehatan pharma medika. 3 (2)

7. Sylvia. R. S., Durry. M, \& Lintong. P.. (2016). Gambaran histopatologik testis tikus wistar (Rattus norvegicus) setelah pemberian monosodium glutamate. Jurnal e-Biomedik (eBm). 4(2)

8. Kalsum. U., Ilyas. S., \& Hutahaean. S.. (2009). Pengaruh pemberian vitamin $\mathrm{C}$ dan $\mathrm{E}$ terhadap gambaran histologis testis mencit (Mus Musculus L.) yang dipajankan monosodium glutamat (MSG). Universitas Sumatera Utara: 7-12.

9. Sa'adah. N., \& Purnomo. W.. (2016). Karakteristik dan perilaku berisiko pasangan infertil di klinik fertilitas dan bayi tabung tiara cita Rumah Sakit Putri Surabaya. Jurnal biometrika dan kependudukan. 5(1): 61-69.

10. Puspitasari. M. L., Wulansari. T. V., Widyaningsih. T. D , Maligan. J. M., \& Nugrahini. N. I. P.. (2016). Aktivitas antioksidan suplemen herbal daun sirsak (Annona muricata L.) dan kulit manggis (Garcinia mangostana L.). Jurnal Pangan dan Agroindustri. 4(1): 283-290

11. Da'I. M., Ratnaningrum. A. D., Wahyuni. A. S., Melannisa. R, \& Trisharyanti. I.. (2012). Uji aktivitas antiradikal ekstrak etanol daun elephantopus schaber L., Ocimum basilicum L. Forma citratum back., Graptophylum pictum griff, dan Gynura procumbens merr. dengan metode dpph (1,1- difenil-2- pikril hidrazil) serta penetapan kadar fenolik totalnya. PHARMACON. 13(2): 41-46.

12. Burducea. M., Lobiuc. A., Costica. N., \& Zamfirache. M. M.. (2016). The influence of Preceding Plant Cultivation on Growthand Physiology of an Ocimum basilicum L. Cultivar. Scientific papers. Series $b$, horticulture. Vol. LX: 225-232.

13. Weldimira. V., Susantiningsih. T., Apriliana. E., \& Sutiyarso.. (2016). The influence of giving ethanolic extract of red ginger (Zingiber officinale roxb var rubrum) to the white rat (Rattus norvegicus) sprague dawley spermatogenic cell count exposed to cigarette smoke. Faculty medicine of Lampung University. ISSN 2337-3776: 173-180

14. Kadir. R. E., Omotoso. G. O., Balogun T. J., \& Oyewovo. A.O.. (2011). Effects of monosodium glutamate on semen quality and the cytoarchitecture of the testis of adult wistar rats . International journal of biomedical and health sciences. 7(1): 3946.

15. Redha, A. 2010. Flavonoid: Struktur, Sifat Antioksidatif Dan Peranannya Dalam Sistem Biologis. Jurnal Belian. 9(2): 196 - 202.

16. Kumar, S. dan A. K. Pandey. (2013). Chemistry and biological activities of flavonoid: an overview. The Scientific World Journal. 1-16

17. Hardiningtyas S. D., Sri P., Ekowati H.,. 2014. Aktivitas antioksidan dan efek hepatoprotektif daun 
bakau api-api putih. JPHPI, 17(1)

18. Sharma N, Shukla S. 2011. Hepatoprotective potential of aqueous extract of Butea monosperma against CCl4 induced damage in rats. In press: 1-11.

19. Khan, D.I., Khan, D.I. \& Khan, D.I. (2011) Phytochemical Constituents and Pharmacological Activities of Sweet Basil- Ocimum basilicum L . ( Lamiaceae ). 23 (9), 3773-3782.

20. Madianung. V., Satiawati. L., \& Tendean L.. (2016). Pengaruh susu kacang kedelai (Glycine max L.Merr.) terhadap kualitas spermatozoa tikus wistar (Rattus norvegicus). Jurnal e-Biomedik (eBm). 4(1): 188-192.

21. Permatasari A. A P. \& Widhiantara I G. (2017). Terapi testosteron meningkatkan jumlah sel leydig dan spermatogenesis mencit (Mus Musculus) yang mengalami hiperlipidemia. Jurnal media sains 1 (2) : 77-83

22. Karnila R.,Made A., Sukarno, \& Tutik W., 2011. Karakteristik konsentrat protein teripang pasir (Holothuria scabra J.) Dengan bahan pengekstrak aseton. Jurnal Perikanan dan Kelautan 16 (1) : 90102

23. Guyton A.C., Hall J.E.2012. Buku ajar fisiologi kedokteran. Edisi 11. Jakarta : Penerbit Buku Kedokteran EGC. 


\section{GAMBAR}

Tabel II. Uji homogenitas data

\begin{tabular}{|c|c|c|c|c|c|c|}
\hline & $\begin{array}{l}\text { Levene } \\
\text { Statistic }\end{array}$ & df1 & df 2 & Sig. & \multicolumn{2}{|c|}{ Wilk } \\
\hline \multirow{4}{*}{$\begin{array}{l}\text { Spermatosit } \\
\text { Spermatid } \\
\text { Jumlah sel }\end{array}$} & 2.715 & 4 & 20 & .059 & df & Sig. \\
\hline & 2.161 & 4 & 20 & .111 & 5 & .919 \\
\hline & 1.812 & 4 & 20 & .166 & 5 & 506 \\
\hline & 1.198 & 4 & 20 & .342 & 5 & .575 \\
\hline & A & & & .918 & 5 & .517 \\
\hline & B & & & .906 & 5 & .444 \\
\hline Spermatosit & $\mathrm{C}$ & & & .859 & 5 & .224 \\
\hline & D & & & .905 & 5 & .439 \\
\hline & $\mathrm{E}$ & & & .924 & 5 & .555 \\
\hline & A & & & .782 & 5 & .057 \\
\hline & B & & & .852 & 5 & .202 \\
\hline Spermatid & $\mathrm{C}$ & & & .956 & 5 & .781 \\
\hline & $\mathrm{D}$ & & & .908 & 5 & .453 \\
\hline & E & & & .910 & 5 & .468 \\
\hline & A & & & .796 & 5 & .075 \\
\hline & B & & & .857 & 5 & .218 \\
\hline Jumlah sel spermatogenik & $\mathrm{C}$ & & & .904 & 5 & .430 \\
\hline & $\mathrm{D}$ & & & .864 & 5 & .242 \\
\hline & $\mathrm{E}$ & & & .899 & 5 & .402 \\
\hline
\end{tabular}



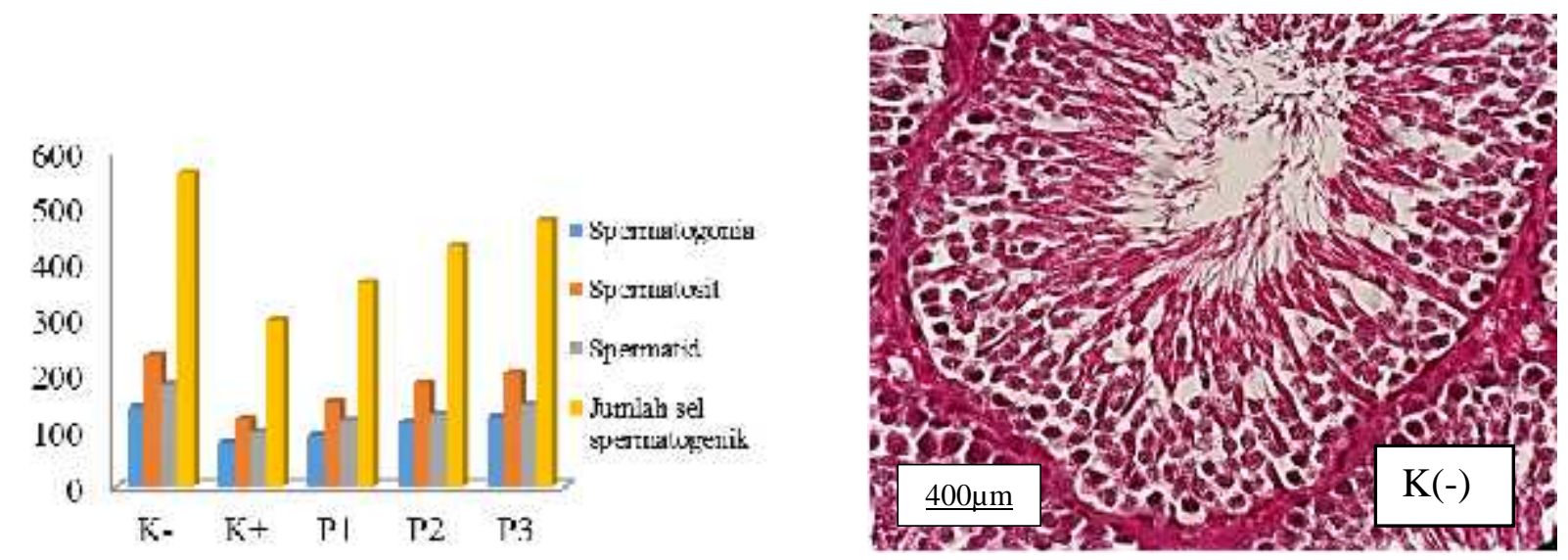

Gambar 1. Diagram batang rata-rata jumlah sel spermatogenik.

kctcrangan:

K- : scbagai kclompok kontrol ncgatit tidak diberikan MSC, alaupun rksltak elanol daun kemangi (thimmm busilitum l.)

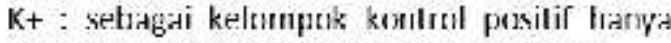
diberikan MSG dengan dosis $7 \% / \mathrm{kgBB} / \mathrm{hari}$

P1 : sebag,ai kelompok perlakuan 1 yang, diberikan MSG dongan dosis $7 \mathrm{~g} / \mathrm{kgBP} / \mathrm{hari}$ komudian diherikan clestrak ctanol daun kemungi (Ocirnum busilicum L.) dengun dosis $8 /, b \mathrm{mg} / \mathrm{kgus} / \mathrm{hami}$

$\boldsymbol{\mu}_{2}$ : sebugai kelornow perlakuan 2 diberikan MSG dengan dosis $7 \mathrm{~g} / \mathrm{kgBB} / \mathrm{hari}$ kemudian dibcrikan ckstrak ctanol daun kemang (orimum bnsilirum 1.) dengan dosis dosis 175 $\mathrm{mg} / \mathrm{kg}$ ß乃/hari,

$\mu_{3}$ : sebapai kelompok perlakuan 3 dempan dasis / p/kp,BB/huri kemudian ffberikan ekstrak elanol daun kemiany \{Ocimarn basilicum L.) dengan dosis $350 \mathrm{mg} / \mathrm{kgBB}$
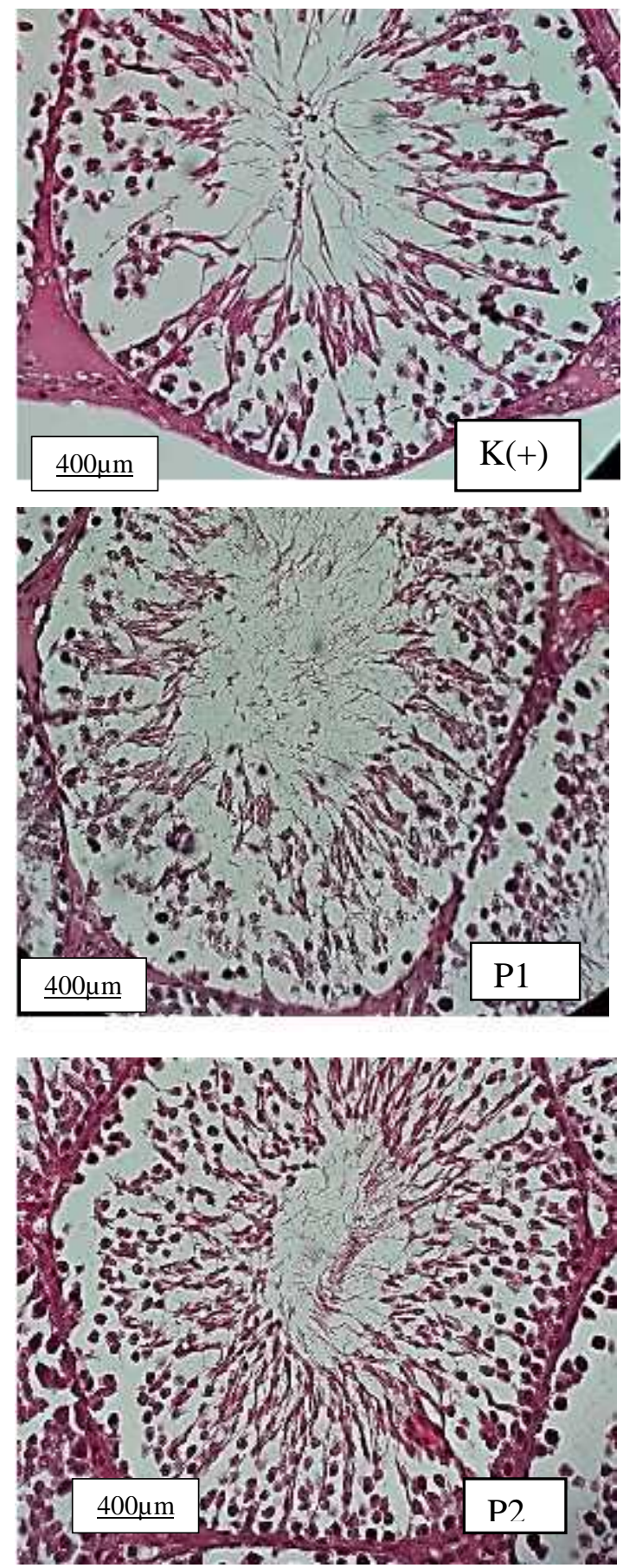


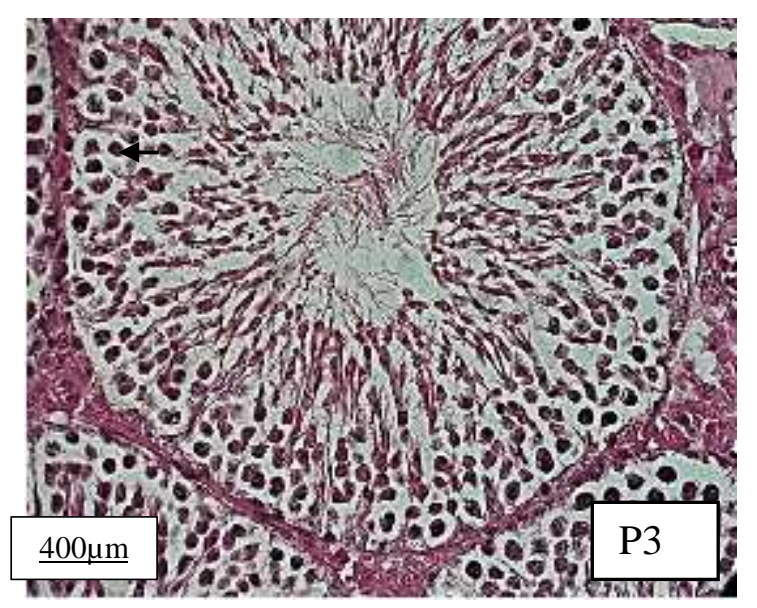

Gambar 2. Tubulus seminiferus testis potongan melintang perbesaran 400x

K- sebagai kelompok kontrol negatif tidak diberikan MSG ataupun ekstrak etanol daun kemangi (Ocimum basilicum L.), K+ sebagai kelompok kontrol positif hanya diberikan MSG dengan dosis $7 \mathrm{~g} / \mathrm{kgBB} /$ hari, $\mathrm{P} 1$ sebagai kelompok perlakuan 1 yang diberikan MSG dengan dosis $7 \mathrm{~g} / \mathrm{kgBB} /$ hari kemudian diberikan ekstrak etanol daun kemangi (Ocimum basilicum L.) dengan dosis $87,5 \mathrm{mg} / \mathrm{kgBB} / \mathrm{hari}$, P2 sebagai kelompok perlakuan 2 diberikan MSG dengan dosis $7 \mathrm{~g} / \mathrm{kgBB} /$ hari kemudian diberikan ekstrak etanol daun kemangi (Ocimum basilicum L.) dengan dosis dosis $175 \mathrm{mg} / \mathrm{kgBB} / \mathrm{hari}, \quad \mathrm{P} 3$ sebagai kelompok perlakuan 3 dengan dosis 7 $\mathrm{g} / \mathrm{kgBB} /$ hari kemudian diberikan ekstrak etanol daun kemangi (Ocimum basilicum L.) dengan dosis $350 \mathrm{mg} / \mathrm{kgBB} /$, (a) sel spermatogonia, (b) sel spermatosit, (c) sel spermatid.

\section{SATUAN UKURAN}

1. Jumlah sel Spermatogenik: Rata-rata jumlah sel

2. Perbesaran mikroskop : 400X

\section{DAFTAR SINGKATAN}

1. ADI: Acceptable Daily Intake

2. FSH: Follicle Stimulating Hormone

3. GnRH: Gonadotropin Releasing Hormone

4. LH: Luteinizing Hormone

5. MSG: Monosodium Glutamat

6. WHO: World Health Organization

7. HE : Hematoxylin-Eosin

8. ROS: Reactive Oxygen Species 
